КОМПЕТЕНТНІСНИЙ ПІДХІД У ФОРМУВАННІ ЕКОЛОГІЧНОЇ КУЛЬТУРИ МАЙБУТНІХ УЧИТЕЛІВ ТРУДОВОГО НАВЧАННЯ ТА ТЕХНОЛОГІЙ

\title{
COMPETENCE APPROACH IN THE FORMATION OF ECOLOGICAL CULTURE OF FUTURE TEACHERS OF LABOR EDUCATION AND TECHNOLOGIES
}

У статті осмислюється місце, роль і можливості компетентнісного підходу у фрормуванні екологічної культури майбутніх учителів трудового навчання та технологій. Вмотивовується нагальна необхідність впровадження нових підходів у професійній підготовці фрахівців, зокрема майбутніх учителів відповідно до вимог компетентнісно орієнтованої європейської освіти, оскільки їхня професійна діяльність спрямована на розвиток компетентностей здобувачів середньої освіти. Орієнтуючись на принципи, закладені в міжнародній програмі «Визначення та відбір компетентностей: теоретичні й концептуальні засади» (DeSeCo), Рекомендації Європейського Парламенту та Ради (ЄC) «Про основні компетенції для навчання протягом усього життя» (2006 р.), Рамку кваліфрікацій Європейського простору, наукові дослідження українських та зарубіжних вчених, уточнено категорії компетентнісного підходу, скориговано уявлення про результат його впровадження, що передбачає наявність у фрахівця компетентностей, які мають динамічний характер, формуються $і$ розвиваються в процесі діяльності, є основою готовності до діяльності та мають якості, що уможливлюють цю діяльність.

Головна увага студії зосереджена на формуванні екологічних компетентностей майбутнього вчителя, узгодженні освітньої діяльності із засадничими документами, зокрема проєктом Стандарту вищої освіти України зі спеціальност 014.10 Середня освіта (Трудове навчання та технології) та Державним стандар том базової середньої освіти (2020), в яких серед основних компетентностей здобувачів освіти визначається екологічна, що передбачає усвідомлення екологічних основ природокористування, необхідності охорони природи, дотримання правил поведінки на природі, ощадливого використання природних ресурсів, розуміння контексту і взаємозв'язку господарської діяльності і збереження природи для забезпечення сталого розвитку суспільства.

У дослідженні визначено групи компетентностей майбутніх учителів трудового навчання та технологій, які засвідчують рівень розвитку їхньої екологічної культури, окреслено екологічну компетентність як підсистему професійної компетентності фахівця, яка стає умовою вдосконалення та розвитку його предметних компетентностей.
Ключові слова: компетентність, екологічна компетентність, учителі трудового навчання та технологій, екологічна освіта, професійна підготовка фрахівців.

The article comprehends the place, role and possibilities of the competence approach in the formation of the ecological culture of future teachers of labor education and technology. There is an urgent need to introduce new approaches in the training of specialists, in particular, future teachers in accordance with the requirements of competence-oriented European education, as their professional activities are aimed at developing the competencies of secondary education. Focusing on the principles enshrined in the International Program "Definition and Selection of Competences: Theoretica and Conceptual Principles" (DeSeCo), Recommendation of the European Parliament and of the Council (EU) on Core Competences for Lifelong Learning (2006), European Qualifications Framework space, research of Ukrainian and foreign scientists, clarified the categories of competency approach, adjusted the idea of the result of its implementation, which implies that the specialist has competencies that are dynamic, formed and developed in the process, are the basis of readiness and have qualities that enable this activity.

The main focus of the study is on the formation of environmental competencies of future teachers, harmonization of educational activities with basic documents, in particular the Draft Standard of Higher Education of Ukraine in specialty 014.10 Secondary education (Labor training and technology) and the State standard of basic secondary education (2020) competencies of students, defined ecological, which involves awareness of the ecological foundations of nature, the need for nature protection, compliance with the rules of nature, economical use of natural resources, understanding the context and relationship of economic activity and the importance of nature conservation to ensure sustainable development.

The study identifies groups of competencies of future teachers of labor training and technology, which certify the level of development of their environmental culture, outlines environmental competence as a subsystem of professional competence of the specialist, which becomes a condition for improving and developing his subject competencies.

Key words: competence, ecological competence, teachers of labor education and technologies, ecological education, professional training. педагогічного університету

імені Володимира Винниченка
Постановка проблеми в загальному вигляді. Рефрорми вищої освіти в Україні, які відбуваються нині, оновлення її змісту відповідно до положень Болонської декларації спрямовані на запровадження загальноєвропейських стандартів в освітній процес, який вибудовується на засадах гуманістичної спрямованості, демократизації, неперервності, ґрунтовності. Однією із сучасних і актуальних проблем розвитку педагогічної теорії і практики, що активно обговорюється вченими, є вдосконалення систем освіти 3 позицій компетентнісного підходу.

Такі зміни потребують впровадження нових підходів у професійній підготовці фрахівців, зокрема 
майбутніх учителів відповідно до вимог компетентнісно орієнтованої європейської освіти, оскільки їхня професійна діяльність спрямована на розвиток компетентностей учня.

Одним із ключових підходів у професійній підготовці вчителів трудового навчання та технологій $€$ компетентнісний підхід. Кваліфікаційні вимоги сучасного фрахівця потребують не тільки знань, умінь і навичок, а й накопичення досвіду їх доцільного використання в щоденній та професійній діяльності. Освіта перефрорматується на забезпечення майбутнього фахівця базовими (ключовими) та фаховими компетентностями.

Відповідно до Рекомендації Європейського Парламенту та Ради (ЄС) «Про основні компетенції для навчання протягом усього життя» (2006 р.), компетенції визначаються як «набір знань, навичок та відношень, що стосуються ситуації. Основні компетенції - це ті, які необхідні всім громадянам для особистої реалізації та розвитку, активного громадянського життя, соціальної єдності та можливості працевлаштування» [9].

У національному освітньому глосарії вищої освіти поняття «компетентність/компетентності» (Competence, competency / competences, competencies) визначається як динамічна комбінація знань, розуміння, умінь, цінностей, інших особистих якостей, що описують результати навчання за освітньою/навчальною програмою. Саме компетентності покладені в основу кваліфікації випускника [5].

Аналіз останніх досліджень і публікацій. Впровадження компетентнісного підходу в освіті $\epsilon$ предметом наукових розвідок українських і зарубіжних науковців. Теоретичні та практичні аспекти вивчення проблем компетентнісного підходу в системі освіти України розглянуті в дослідженнях таких науковців: І.Д. Беха, О.В. Биковської, Н.М. Бібік, В.М. Боголюбова, О.І. Гури, О.С. Заблоцької, О.М. Коберника, Л.Б. Лук'янової, Н.Г. Ничкало, О.В. Овчарук, О.І. Пометун, О.П. Савченко, А.В. Хуторського та ін.

Перед суспільством постають питання: що необхідно людині, щоб мати успішне життя в сучасному суспільстві, бути відповідальною та здатною відповідати на нинішні та майбутні виклики? Якими $\epsilon$ нормативні, теоретичні та концептуальні основи для визначення та вибору обмеженого набору найбільш відповідних компетенцій? Відповіді на ці питання знаходимо в міжнародних документах та дослідженнях науковців. Так, теоретичні основи, обґрунтування визначення та процесу відбору ключових компетенцій та їх зв'язок із соціальним та економічним середовищем стали предметом дослідження міжнародної програми «Визначення та відбір компетентностей: теоретичні й концептуальні засади» (DeSeCo), прийнятої ще наприкінці 1997 р. У програмі наголошено на фрормуванні в людини, насамперед, ключових компетентностей, які мають логічну послідовність: вивчати шукати - думати - співпрацювати - діяти - адаптуватись [14, с. 6].

Прийнята у 2005 р. Рамка кваліфрікацій Європейського простору вищої освіти визначає результати та досягнення кожного завершеного рівня вищої освіти. Для загального опису типових очікуваних досягнень та здатностей випускника для кожного циклу (рівня) використовуються Дублінські дескриптори (Dublin descriptors), які фрормулюються 3 точки зору рівнів компетентності, а не результатів навчання, і дають змогу широко і загалом розрізняти різні цикли. Дескриптор рівня включає такі п'ять компонентів (види компетентностей):

1) знання та розуміння;

2) застосування знань та розуміння;

3) фрормування суджень;

4) спілкування (комунікація);

5) навички навчання протягом усього життя $[13$, с. 9].

Виділення не вирішених раніше частин загальної проблеми. Значна кількість наукових робіт присвячена проблемі впровадження компетентнісного підходу. Попри це, компетентнісний підхід у розвитку екологічної культури майбутніх учителів трудового навчання та технологій до останнього часу не був у полі спеціальних досліджень науковців. Це зумовило вибір теми дослідження.

Мета статті - охарактеризувати компетентнісний підхід у розвитку екологічної культури майбутніх учителів трудового навчання та технологій.

Виклад основного матеріалу. Стрімкий розвиток науково-технічного прогресу та інфрормаційних процесів, швидке технологічне оновлення виробництва, практичне застосування у виробничому процесі досягнень науки і техніки вимагають фрахівця нового типу - активного, відповідального, такого, що вміє працювати в команді, спроможний швидко адаптуватися до мінливих умов сьогодення, здатний до самонавчання.

Характеризуючи поняття «компетентнісний підхід» та наголошуючи на спрямованості освітнього процесу на фрормування та розвиток ключових (базових, основних), загальногалузевих та предметних компетентностей особистості, O.І. Пометун зазначає: «Результатом такого процесу буде формування загальної компетентності людини, що $€$ сукупністю ключових компетентностей, інтегрованою характеристикою особистості» [7, с. 149].

Характеризуючи компетентнісний підхід 3 огляду модернізації підготовки фахівців, Ю.В. Сухарніков наголошує, що такий підхід збільшує не лише обсяг знань студента, а й сприяє фрормуванню системи умінь, навичок та досвіду, 
які необхідні випускнику для здійснення продуктивної професійної діяльності [11].

Сучасні психолого-педагогічні дослідження визначають компетентнісний підхід як основу для побудови парадигми професійно-педагогічної діяльності майбутнього педагога, орієнтованої на фрормування професійної компетентності як інтегративної характеристики, що визначає здатність розв'язувати професійні завдання, які виникають у реальних ситуаціях професійно-педагогічної діяльності, з використанням знань, досвіду, цінностей і нахилів особистості. Підтверджує цю думку розуміння компетентнісного підходу Н.В. Нагорною, яка стверджує, що такий підхід має в основі не поінорормованість студентів, а вміння розв'язувати проблеми, що виникають у пізнавальній, технологічній і психологічній діяльності, у сорерах етичних, соціальних, правових, професійних, особистих взаємин. 3 огляду на це зазначений підхід передбачає такий вид змісту освіти, який не зводиться до знаннєво орієнтованого компонента, а передбачає цілісний досвід вирішення життєвих проблем, виконання ключових функцій, соціальних ролей, компетенцій [4].

Основоположними категоріями компетентнісного підходу $€$ «компетенція» та «компетентність», які потребують уточнення, адже іноді ці терміни вживаються як синонімічні. Так, науковець В. Моштук, досліджуючи фрахові компетентності вчителя трудового навчання [3, с. 108], зазначає, що похідним компонентом усіх видів компетентності $€$ фрахова - інтегративна характеристика особистості, яка виступає показником освіченості (наявності професійної освіти) та а) проявляється в готовності до успішного здійснення професійної діяльності, б) є переліком умов для фрахівця в конкретній сорері, в) визначає фрахово важливі знання і вміння, особистісні та мотиваційні компоненти діяльності, усвідомлення її соціальної значущості і відповідальне ставлення до справи [3, с. 109].

У науковому доробку О.Є. Антонової та Л.П. Маслак ці категорії визначені так: під компетентністю автори розуміють гармонійне, інтегроване, системне поєднання знань, умінь і навичок, норм, емоційно-ціннісного ставлення та рефлексії, що становлять мінімальну готовність особистості до вирішення практичних завдань [1, с. 97]. Компетенція - це інтегративна характеристика особистості, що містить систему знань, умінь та навичок, які є необхідними для здійснення ефективної діяльності в певній галузі [1, с. 109].

Розглядаючи проблеми компетентнісного підходу у вищій освіті, Ю. Панфілов та Б. Фурманець зазначають, що всередині цього підходу виділяються два базових поняття: компетенція (розглядається як сукупність якостей особистості, узагальнених інтелектуальних, профресійних, комунікативних, методологічних, світоглядних та інших умінь) і компетентність (володіння відповідною компетенцією, що включає особистісне ставлення до неї і предмета діяльності) [6, с. 62]. Автори наголошують на реалізації компетентнісного підходу через інтеграцію теорії і практики, побудові освітнього процесу на самостійній діяльності студентів «через власну практику і помилки» під керівництвом викладача.

Науковець В. Стешенко визначає компетентності фрахівця як такі, що фрормуються через трудові функції, типові завдання діяльності та професійні уміння [10, с. 216]. На думку автора, зміст професійної освіти має фрормуватися на основі відповідних профресійних задач, що входять до складу профресійних фрункцій чи видів діяльності фрахівця певної професії, спеціальності та кваліфрікації, а не на основі суб'єктно-діяльнісного підходу, певних наук чи окремих систем вимог.

Традиційний кваліфікаційний підхід окреслює вимоги до змісту освіти, визначає ті знання, вміння і навички, якими має володіти випускник закладу вищої освіти, щоб успішно реалізуватися у професійній діяльності. Компетентнісний підхід передбачає наявність у фрахівця здатності застосовувати ці знання, уміння і навички для розв'язання завдань, які постають перед фахівцем у професійній діяльності, прагненні до саморозвитку. 3 цієї позиції профресійну компетентність учителя розглядають О. Дубасенюк та О. Вознюк, які визначають її як здатність фрахівця кваліфіковано й ефективно застосовувати теоретичні знання, знання-засоби, знання-цінності в запланованих і непередбачених педагогічних ситуаціях [2, с. 11-18]. Таким чином, компетентнісний підхід передбачає наявність у фрахівця компетентностей, які мають динамічний характер, фрормуються і розвиваються у процесі діяльності, $€$ основою готовності до діяльності та мають якості, що уможливлюють цю діяльність.

Погоджуємося з С. Ящуком: «Нині фрормується нова картина світу, в якій ознаками науки є: співіснування безлічі концепцій, гіпотетична неоднозначність інтерпретації результатів, метафоричне зближення наукових і ненаукових фрорм пізнання. Критерій «правильно - неправильно» заступає критерій «корисно - ефективно - нешкідливо». Стає зрозумілим, що майбутнє залежить не від кількості знань, а від рівня культури й здатності людини до орієнтації в нестандартних ситуаціях або в ситуаціях стандартних, але ще їй не відомих» [12, с. 59].

3 огляду на те, що подальша педагогічна діяльність майбутнього учителя трудового навчання та технологій базується на інтеграції психолого-педагогічних, технічних наук та основ виробництва 3 активною взаємодією з технологічним середовищем, важливим $€$ формування екологічної компетентності такого фрахівця, яку зараховуємо до предметних. Проєкт Стандарту вищої освіти Укра- 
їни (2017) зі спеціальності 014.10 Середня освіта (Трудове навчання та технології) 3-поміж предметних компетентностей і програмних результатів навчання випускника визначає знання екологічних питань техніки і виробництва, будови й принципів дії технічних систем, здатність до організації та проведення позакласної та позашкільної роботи для здійснення предметно-перетворювальної діяльності в закладах освіти, здатність організовувати контроль захисту довкілля.

Крім того, Державний стандарт базової середньої освіти (2020) серед основних компетентностей здобувачів середньої освіти визначає екологічну, яка передбачає усвідомлення екологічних основ природокористування, необхідності охорони природи, дотримання правил поведінки на природі, ощадливого використання природних ресурсів, розуміння контексту і взаємозв'язку господарської діяльності і важливості збереження природи для забезпечення сталого розвитку суспільства.

Відповідно, зростають вимоги до екологічної компетентності вчителя, адже від рівня її сорормованості залежатиме якість екологічної освіти здобувачів освіти 33СО, виховання в них відповідального ставлення до навколишнього середовища, розвиток здатності будувати своє життя відповідно до парадигми сталого розвитку.
У дослідженні нами визначено групи компетентностей майбутніх учителів трудового навчання та технологій, які засвідчують рівень розвитку їхньої екологічної культури (Таблиця 1).

Формування готовності майбутніх учителів трудового навчання та технологій до еколого орієнтованої педагогічної діяльності має відбуватися цілеспрямовано в площині формування їхніх ключових, предметних, методичних компетентностей. При цьому екологічна компетентність розглядається як складник загальної професійної компетентності, яка зумовлює діяльнісну, практичну та особистісну направленість і визначає важливість набуття досвіду для виконання професійних завдань.

Висновки. Впровадження компетентнісного підходу в підготовці майбутніх учителів трудового навчання та технологій, розвитку їхньої екологічної культури має бути спрямоване на підготовку майбутнього фрахівця, який уміло може застосувати свої знання, уміння і навички в професійній діяльності, здатного до прийняття креативних рішень у нестандартних ситуаціях, готового до постійного саморозвитку та самовдосконалення. Екологічна компетентність $€$ підсистемою профресійної компетентності такого фахівця, стає умовою вдосконалення та розвитку його предметних компетентностей.

Таблиця 1

\section{1. Знання з предметної області}

1.1. Базові знання з основних понять і термінів екологічної освіти, її основних законів та методик її реалізації.

1.2. Знання екологічних фракторів, ресурсів, різноманіття основних типів взаємодії «людина-природа».

1.3. Вміння застосовувати основні закони, закономірності, правила і принципи екології, знати глобальні проблеми екології, проблеми екологічної безпеки, методику організації екологічної освіти.

1.4. Знання ЗУ «Про охорону навколишнього середовища», положень Концепції екологічної освіти України.

1.5. Володіння компетентністю реалізації еколого-перетворювальної та еколого-збережувальної профресійної діяльності.

\section{3. Практичні навички з предметної області}

3.1. Навички проводити якісну та кількісну оцінку впливу профресійної технологічної діяльності на природні ресурси та стан оточення.

3.2. Здатність до використання основних принципів та складників екологічної освіти.

3.3. Здатність проводити екологічний моніторинг та оцінювати поточний стан навколишнього середовища.

3.4. Здатність обґрунтовувати необхідність та розробляти виховні заходи, спрямовані на збереження природних ресурсів і розвиток екологічної культури учнівської молоді.

3.5. Здатність до використання сучасних інформаційних технологій у профресійній діяльності.

3.6. Здатність до опанування до міжнародного та вітчизняного досвіду розв'язання екологічних проблем.

\section{2. Когнітивні уміння та навички} з предметної області

2.1. Здатність до розв'язання проблемних екологічних ситуацій, застосовувати знання дії законів у сучасних проблемах.

2.2. Уміння давати професійну екологічну оцінку стану природних компонентів, пояснювати технологічні процеси законами екології.

2.3. Здатність реалізації екологічної освіти.

2.4. Уміння виявляти негативні екологічні тенденції в еколого-перетворювальній діяльності.

2.5. Здатність на основі отриманих результатів про стан усіх природних компонентів дати загальну характеристику стану екологічної ситуації загалом.

\section{4. Загальні уміння та навички}

4.1. Здатність діагностувати власні стани та почуття 3 метою забезпечення ефективної та безпечної діяльності.

4.2. Уміння визначати цілі та завдання власної профресійно-педагогічної діяльності на основі усвідомлення мети діяльності та її структури.

4.3. Здатність організовувати власну роботу як складник колективної діяльності.

4.4. Уміння планувати власні дії в умовах еколого-перетворювальної діяльності на основі усвідомлення мети діяльності та її структури.

4.5. Уміння застосовувати прагматичну компетенцію 3 метою ефективного виконання професійних завдань в умовах усних ділових контактів із використанням прийомів і методів усного спілкування і відповідних комунікативних методів. 
БІБЛІОГРАФІЧНИЙ СПИСОК:

1. Антонова О.Є., Маслак Л.П. Профресійна педагогічна освіта: компетентнісний підхід : монографія / за ред. О.А. Дубасенюк. Житомир : Вид-во ЖДУ ім. І. Франка, 2011. С. 81-109.

2. Дубасенюк О.А., Вознюк О.В. Професійна педагогічна освіта: компетентнісний підхід : монограсрія. Житомир : Вид-во ЖДУ ім. І. Франка, 2011. C. 11-18.

3. Моштук В. Фахова компетентність як основа проектно-технологічної культури майбутнього вчителя трудового навчання. Молодь і ринок. 2011. № 7. С. 108-112.

4. Нагорна Н.В. Формування у студентів понять компетентності й компетенції. Виховання і культура. 2007. № 1-2 (11-12). С. 266-268.

5. Національний освітній глосарій: вища освіта / Авт.-укл.: Бабин І.І., Болюбаш Я.Я., Гармаш А.А. й ін. / За наук. ред. В.І. Лугового і Є.М. Суліми. Київ : ТОВ «Видавничий дім «Плеяди», 2010. 100 с.

6. Панфрілов Ю., Фурманець Б. Компетентнісний підхід в освіті: досвід, проблеми, перспективи. Теорія і практика управління соціальними системами: фрілософрія, психологія, педагогіка, соціологія. 2017. № 3. С. 55-67.

7. Пометун O.I. Реалізація компетентнісного та діяльнісного підходів у сучасному підручнику історії. Український педагогічний журнал. 2015. № 2. С. 146-157.

8. Про деякі питання державних стандартів повної загальної середньої освіти : Постанова КМУ від 30 вересня 2020 р. № 898. URL: https://www.kmu.gov. ua/npas/pro-deyaki-pitannya-derzhavnih-standartivpovnoyi-zagalnoyi-serednoyi-osviti-i300920-898 (дата звернення: 12.11.2020)

9. Про основні компетенції для навчання протягом усього життя : Рекомендація 2006/962/ ЄС Європейського Парламенту та Ради (ЄС) від 18 грудня 2006 р. URL: https://zakon.rada.gov.ua/laws/ show/994_975\#Text (дата звернення: 16.11.2020)

10. Стешенко В.В. Використання компетентнісного підходу при складанні галузевого стандарту освітньо-кваліфрікаційної характеристики професійної підготовки вчителя технологій. Вісник Чернігівського національного педагогічного університету : Серія «Педагогічні науки». 2011. Вип. 88. С. 215-218.

11. Сухарніков Ю.В. Сутнісні розбіжності «діяльнісного» $\mathbf{i}$ «компетентнісного» підходів до стандартизації освіти України у контексті Болонських рекомендацій. Педагогіка і психологія. 2009. № 2. С. 32-42.

12. Ящук С.М. Профресійна підготовка викладача загальнотехнічних дисциплін: теоретичний аспект : навчальний посібник. Умань : ФОП Жовтий О.О., 2015. 133 с.

13. Bologna Follow-Up Group (2005) Framework for Qualifications of the European Higher Education Area. Kopenhagen.

14. Definition and Selection of Competencies. Theoretical and Conceptual Foundations (DESECO): Strategy Paper on Key Competencies. An Overarching Frame of Reference for an Assessment and Research Program - OECD (Draft). Quality education and competencies for life. Workshop 3. Background Paper, 2004. № 34 . 